\title{
Menguji Ulang Keabsahan Akad Sewa Menyewa Berdasarkan Prinsip Ijarah Muntahiya Bittamlik Pada Bank Syariah
}

\author{
R. Susetiyo Kukuh Kurnianto \\ Graduate Student, Graduate School of Notary, University of Mataram \\ kukuhsusetiyo@yahoo.com
}

Submitted: 2017-09-11; Reviewed: 2017-09-15; Accepted: 2017-11-27

\begin{abstract}
The aims of this study was to explain the validity of the lease contract based on the principle of Ijarah Muntahiya Bittamlik on sharia bank, to explain the transfer of rights of Ijarah Muntahiya Bittamlik contract object which states the grant promise in accordance with sharia principles, and to explain the legal protection against Mustajir in Ijarah Muntahiya Bittamlik based on Principle of Sharia.This research is normative legal research, and used legislation and conceptual approach. Analysis of legal materials was done by analyzing various regulations that specifically regulate the contract of Lease Rent Based on Ijarah Muntahiya Bittamlik Principle. Based on the results of the research that the validity of Ijarah Muntahiya Bittamlik must be in accordance with the rules and conditions stipulated in accordance with Law Number 21 of 2008 concerning Sharia Banking, Compilation of Islamic Economic Law, and other related rules. That Ijarah Muntahiya Bittamlik based on the transtition of ownership of objects with the condition (waad) of grant is not valid. That the protection of the Law against Mustajir in Ijarah Muntahiya Bittamlik based on Sharia Principle is in the form of protection of preventive law.
\end{abstract}

Keywords: Contract, Ijarah Muntahiya Bittamlik, Validity, Protection, Law.

\section{PENDAHULUAN}

Dalam Pasal 1 ayat (25) huruf b UndangUndang Nomor 21 Tahun 2008 tentang Perbankan Syariah menyatakan pembiayaan adalah penyediaan dana atau tagihan yang dipersamakan dengan itu berupa transaksi sewa-menyewa, dalam bentuk Ijarah atau sewa beli dalam bentuk Ijarah Muntahiya Bittamlik.

Ijarah Muntahiya Bittamlik adalah sewa-menyewa antara pemilik objek sewa dengan penyewa untuk mendapatkan imbalan atas objek sewa yang disewakan dengan opsi perpindahan hak milik objek sewa dengan jual beli atau pemberian (hibah) pada saat tertentu sesuai akad sewa. Dalam Ijarah Muntahiya Bittamlik, pemindahan hak milik barang terjadi dengan salah satu dari dua cara sebagai berikut:

1. Pihak yang menyewakan berjanji 
akan menjual barang yang disewakan tersebut pada akhir masa sewa;

2. Pihak yang menyewakan berjanji akan menghibahkan barang yang disewakan tersebut pada akhir masa sewa. ${ }^{1}$

Dalam perumusan akad Ijarah Muntahiya Bittamlik para pihak, harus sesuai dengan ketentuan Undang-Undang Nomor 21 Tahun 2008 tentang Perbankan Syariah, Peraturan Mahkamah Agung Nomor 2 Tahun 2008 tentang Kompilasi Hukum Ekonomi Syariah dan Fatwa Dewan Syariah Nasional Nomor: 27/DSNMUI/iii/2002 tentang Al-Ijarah AlMuntahiyah BI Al-Tamlik. Pasal 280 Kompilasi Hukum Ekonomi Syariah menyatakan bahwa:

1. Ijarah Muntahiyah Bi Tamlik harus dinyatakan secara eksplisit dalam akad.

2. Akad pemindahan kepemilikan hanya dapat dilakukan setelah masa Ijarah Muntahiyah Bi Tamlik berakhir.

Kemudian diatur lebih lanjut oleh ketentuan Fatwa Dewan Syariah Nasional Nomor: 27/DSN-MUI/iii/2002 tentang AlIjarah Al-Muntahiyah Bi Al-Tamlik yang menyatakan bahwa:

1. Pihak yang melakukan Al-Ijarah Al-Muntahiah Bi Al-Tamlik harus melaksanakan akad Ijarah terlebih dahulu. Akad pemindahan kepemilikan, baik dengan jual beli atau pemberian, hanya dapat dilakukan setelah masa Ijarah selesai.

\footnotetext{
1 Faturrahman Djamil, Penerapan Hukum Perjanjian dalam Transaksi di Lembaga Keuangan Syariah, Jakarta: Sinar Grafika, 2013, hlm.156.
}

2. Janji pemindahan kepemilikan yang disepakati di awal akad Ijarah adalah Wa'ad yang hukumnya tidak mengikat. Apabila janji itu ingin dilaksanakan, maka harus ada akad pemindahan kepemilikan yang dilakukan setelah masa Ijarah selesai.

Adapun ketentuan Kompilasi Hukum Ekonomi Syariah tentang keabsahan Akad Ijarah Muntahiya Bittamlik menentukan bahwa opsi peralihan hak kepemilikan objek adalah dengan janji jual beli. Hal tersebut lebih ditegaskan pada ketentuan pasal 279 Kompilasi Hukum Ekonomi Syariah, Dalam akad Ijarah Muntahiya Bittamlik suatu benda antara mu'jir/pihak yang menyewakan dengan musta'jir/pihak penyewa diakhiri dengan pembelian ma'jur/obyek ijarah oleh musta'jir/pihak penyewa.

Sehingga belum ada pengaturan secara jelas tentang Akad Ijarah Muntahiya Bittamlik berdasarkan peralihan kepemilikan objek dengan janji (waad) hibah. pengalihan kepemilikan objek perjanjian dengan janji (waad) Hibah terdapat pada ketentuan Fatwa Dewan Syariah Nasional Nomor: 27/DSNMUI/iii/2002 tentang Al-Ijarah AlMuntahiyah Bi Al-Tamlik.

Dalam akad Ijarah Muntahiya Bittamlik pihak yang melakukan kesepakatan adalah $M u$ 'jiratau pihak yang menyewakan dan Musta'jir atau pihak penyewa. Kedua pihak tersebut masingmasing memiliki kewajiban untuk dipenuhi dalam akad tersebut, hal tersebut dapat 
dilihat seakan tidak sesuai dengan konsep akad Ijarah Muntahiya Bittamlik apabila dilakukan kesepakatan $W a$ 'ad hibah untuk peralihan hak atas objek akad. Berdasarkan ketentuan Kompilasi Hukum Ekonomi Syariah Pasal 693, Ijab dalam hibah dapat dinyatakan dengan kata-kata, tulisan, atau isyarat, yang mengandung arti beralihnya kepemilikan harta secara cuma-cuma. Artinya hibah terjadi tanpa adanya kontra prestasi dari pihak penerima hibah.

Dari pernyataan tersebut terdapat suatu kekaburan norma yang menimbulkan ketidakpastian hukum pada akad Ijarah Muntahiya Bittamlik yang mencantumkan janji hibah untuk peralihan hak kepemilikan objek akad dalam suatu aturan kepastian hukum sangat penting. Kepastian di sini bukan semata-mata formal seperti apa yang tersurat dalam hukum, tetapi kepastian yang dalam pelaksanaannya mengandalkan orientasi. Kepastian tersebut menuntut agar terjadi kekaburan atau penafsiran yang berbeda-beda terhadap suatu aturan. $^{2}$

Dalam penelitian ini penulis mengkaji Keabsahan Akad Sewa-menyewa Berdasarkan Prinsip Ijarah Muntahiya Bittamlik Pada Bank Syariah, Peralihan Hak Objek Akad Ijarah Muntahiya Bittamlik Yang Mencantumkan Janji Hibah Sesuai Dengan Prinsip Syariah, dan Perlindungan Hukum Terhadap Mustajir Dalam Akad Ijarah Muntahiya Bittamlik Berdasarkan Prinsip Syariah?

\footnotetext{
2 Dewi Sartika Utami, “Akibat Hukum Pemberian Hibah yang Melebihi Batas legitime Portie (Analisis Kasus Putusan Pengadilan Negeri Nomor 109/pdt.g/2009/pn.mtr. Mengenai Hibah)", JURNAL IUS | Vol IV | Nomor 2 | Agustus 2016, hlm. 101.

${ }^{3}$ Pusat dan pengembangan ekonomi Islam (P3EI) Universitas Islam Indonesia Yogyakarta
}

\section{PEMBAHASAN}

\section{Keabsahan Akad Sewa Menyewa Berdasarkan Prinsip Ijarah Muntahiya Bittamlik Pada Bank Syariah}

Ekonomi Islam dibangun atas dasar agama, jadi merupakan bagian tak terpisahkan dari agama Islam. Ekonomi Islam akan mengikuti agama Islam dalam berbagai aspeknya. Islam adalah sistem kehidupan (way of life), dikarenakan Islam telah menyediakan berbagai perangkat aturan yang lengkap bagi kehidupan manusia, termasuk dalam bidang ekonomi. ${ }^{3}$

Aspek perlindungan dan kepastian hukum dalam penerapan asas perjanjian dalam akad atau kontrak di setiap Lembaga dan transaksi ekonomi Syari'ah menjadi sangat urgen diupayakan implementasinya. 4 Menurut UndangUndang Nomor 21 Tahun 2008 tentang Perbankan Syariah, bank syariah adalah bank yang menjalankan kegiatan usahanya berdasarkan prinsip syariah dan menurut jenisnya terdiri atas bank umum Syariah dan bank pembiayaan rakyat syariah. Sedangkan perbankan syariah adalah segala sesuatu yang menyangkut tentang Bank Syariah dan Unit Usaha Syariah, mencakup kelembagaan, kegiatan usaha, serta cara dan proses dalam melaksanakan kegiatan usahanya.

Peranan bank sangatlah penting bagi perekonomian suatu negara untuk mendukung pembangunan, karena pembangunan ekonomi di suatu negara sangat bergantung kepada dinamika

berkerjasama dengan Bank Indonesia, Ekonomi Islam, Jakarta: Raja Grafindo Persada, 2008, hlm. 13.

${ }^{4}$ Ahmad, "Penyelesaian Sengketa Ekonomi syariah di Pengadilan Agama", JURNALIUS | Vol II | Nomor 6 | Desember 2014. 
perkembangan dan kon-tribusi nyata dari sektor perbankan. ${ }^{5}$ Bank merupakan badan usaha yang dalam kegiatan usahanya berperan sebagai lembaga intermediasi antara pihak yang memiliki dana dengan pihak yang membutuhkan dana $^{6}$

Jadi sebagai badan usaha Bank Syariah memiliki suatu tujuan yaitu menurut Pasal 3 Undang-Undang Nomor 21 Tahun 2008 tentang Perbankan Syariah, perbankan syariah bertujuan menunjang pelaksanaan pembangunan nasional dalam rangka meningkatkan keadilan, kebersamaan, dan pemerataan kesejahteraan rakyat. Berhubung sifatnya yang berdasarkan prinsip syariah, maka produk syariah itu tidak sama dengan produk-produk bank konvensional, yaitu di antaranya bank maupun nasabah tidak diperkenankan menerima bunga. Akan tetapi jika ada hasil maka hasil tersebutlah yang dibagi antara bank dan pihak nasabah. Selain itu, produkproduk dari bank syariah harus disesuaikan dengan ajaran-ajaran Islam yang melarang riba. $^{7}$

Pada dasarnya pendapatan bank adalah berdasarkan total biaya yang dikeluarkan bank pada tahun berjalan kemudian ditambahkan keuntungan yang hendak diperoleh bank. ${ }^{8}$ Dalam lembaga keuangan Islam atau syariah, akad yang dilakukan memiliki konsekuensi duniawi dan ukhrawi karena akad yang dilakukan berdasarkan hukum Islam. ${ }^{9}$

\footnotetext{
${ }^{5}$ Luh Putu Vera Astri Pujyanti dan Amelia Kandisa, "Penyelesaian Sengketa Perbankan Melalui Mediasi Perbankan", JURNALIUS | Vol III | Nomor 8 | Agustus; 2015, hlm. 223.

${ }^{6}$ Ida Ayu Wayan Meryawira Sendidevi, 'Perlindungan Konsumen Dalam Pemberian Jasa Layanan Perbankan Dan Sistem Pembayaran Melalui ReKening Ponsel Cimb Niaga", JURNAL IUS | Vol III | Nomor 9 | Desember 2015, , hlm 543
}

\section{Rukun dan Syarat Akad Ijarah Muntahiya Bittamlik}

Akad Ijarah Muntahiya Bittamlik merupakan salah satu produk pendanaan pada bank syariah. Untuk keabsahannya, akad Ijarah Muntahiya Bittamlik haruslah memenuhi rukun dan syarat menurut ketentuan Kompilasi Hukum Ekonomi Syariah. Karena merupakan salah satu dari Ijarah, Ijarah Muntahiya Bittamlik haruslah memenuhi rukun dan syarat dari Ijarah, Pasal 278 menentukan bahwa rukun dan syarat dalam ijarah dapat diterapkan dalam pelaksanaan Ijarah Muntahiya Bittamlik. Pasal 251 Kompilasi Hukum Ekonomi Syariah menentukan Rukun Ijarah adalah:

1) Pihak yang menyewa;

2) Pihak yang menyewakan;

3) Benda yang diijarahkan;

4) Akad.

\footnotetext{
${ }^{7}$ Rachmandi Usman, Aspek Hukum Perbankan di Indonesia, Jakarta: Gramedia Pustaka Utama, 2001, hlm. 208.

8 Chandra Natadipurba, Ekonomi Islam 101, Bandung: Mobidelta Indonesia, 2015, hlm, 306.

${ }^{9}$ Lukman Hakim, Prinsip-prinsip Ekonomi Islam, Surakarta: Erlangga, 2012, hlm. 186.
} 
Pada klausul akad Ijarah Muntahiya Bittamlik terdapat ketentuan yang mewajibkan menjelaskan pihak yang menyewa, pihak yang menyewakan, benda yang diijarahkan, tujuan akad.

1. lahir

di. pada tanggal

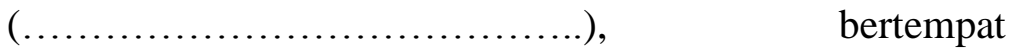
tinggaldi Pemegang Kartu

Tanda Penduduk Nomor : ; dalam hal ini bertindak selaku Pemimpin Cabang PT. BANK Untuk selanjutnya disebut "BANK"

2. pekerjaan beralamat di

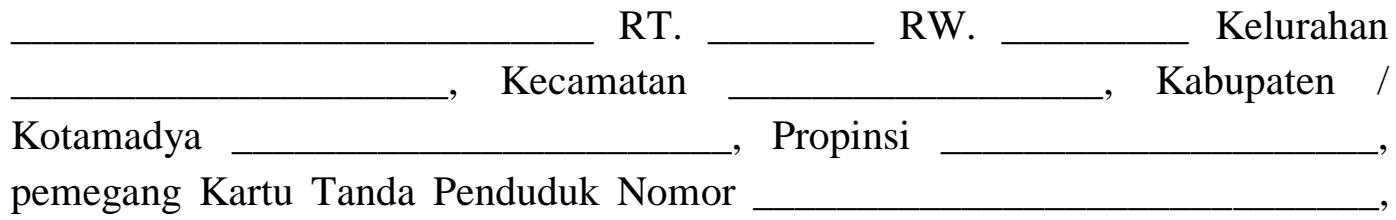

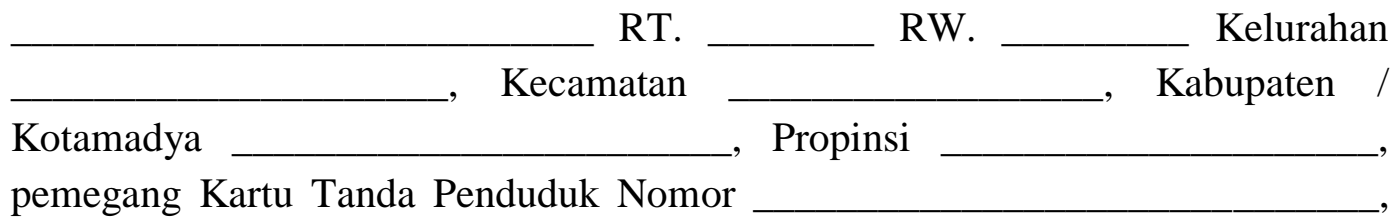

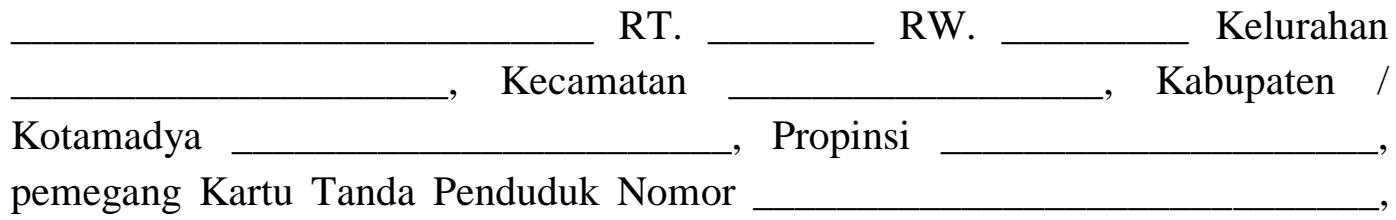
dalam hal ini bertindak untuk diri sendiri dan untuk melakukan tindakan hukum dalam Akad ini telah mendapat persetujuan dari istri/suami*) yaitu ............................., KTP. Nomor: / sebagaimana ternyata dalam Surat Nomor: tertanggal $\left.:^{*}\right)$

Untuk selanjutnya disebut sebagai "NASABAH.

Pencantuman identitas para pihak dalam akad Ijarah Muntahiya Bittamlik adalah untuk menjelaskan bahwa para pihak yang mengikatkan dirinya dalam akad tersebut sebagai subjek hukum yang cakap dalam melakukan tindakan hukum. Sesuai dengan ketentuan pasal 2 Kompilasi Hukum Ekonomi Syariah pihak yang dapat melakukan tindakan hukum adalah:

1) Seseorang dipandang memiliki kecakapan untuk melakukan perbuatan hukum dalam hal telah mencapai umur paling rendah 18 (delapan belas) tahun atau pernah menikah;

2) Badan usaha yang berbadan hukum atau tidak berbadan hukum, dapat melakukan perbuatan hukum dalam hal tidak dinyatakan taflis/pailit berdasarkan putusan pengadilan yang telah memperoleh kekuatan hukum tetap.

Dalam klausul akad harus mencantumkan dengan jelas tujuan akad dan objek yang diperjanjikan dan tujuan dibentuknya akad oleh para pihak.

BANK dengan ini sepakat untuk menyediakan fasilitas pembiayaan IMBT dengan cara menyewakan Obyek Sewa kepada NASABAH dan NASABAH sepakat untuk menyewa dari BANK Obyek Sewa yaitu:

sebagaimana diuraikan dalam Lampiran 2 yang merupakan satu kesatuan dan bagian tidak terpisahkan dari Akad ini *), dengan opsi pengalihan hak/kepemilikan atas Obyek Sewa dari BANK kepada 
NASABAH.

Pencantuman tujuan akad bertujuan agar para pihak mengetahui tujuan dan kesepakatan yang dibuat oleh para pihak. Menurut Penjelasan Atas Undang-Undang Nomor 21 Tahun 2008 tentang Perbankan Syariah Pasal 2 Kegiatan usaha yang berasaskan Prinsip Syariah, antara lain, adalah kegiatan usaha yang tidak mengandung unsur:

1) Riba, yaitu penambahan pendapatan secara tidak sah (batil) antara lain dalam transaksi pertukaran barang sejenis yang tidak sama kualitas, kuantitas, dan waktu penyerahan (fadhl), atau dalam transaksi pinjam-meminjam yang mempersyaratkan Nasabah Penerima Fasilitas mengembalikan dana yang diterima melebihi pokok pinjaman karena berjalannya waktu (nasi'ah);

2) Maisir, yaitu transaksi yang digantungkan kepada suatu keadaan yang tidak pasti dan bersifat untung-untungan;

3) Gharar, yaitu transaksi yang objeknya tidak jelas, tidak dimiliki, tidak diketahui keberadaannya, atau tidak dapat diserahkan pada saat transaksi dilakukan kecuali diatur lain dalam syariah;

4) Haram, yaitu transaksi yang objeknya dilarang dalam syariah; atau

5) Zalim, yaitu transaksi yang menimbulkan ketidakadilan bagi pihak lainnya.

Berdasarkan pernyataan tersebut untuk keabsahanya berdasarkan prinsip syariah, kesepakatan dan objek dalam akad Ijarah
Muntahiya Bittamlik, tidak boleh ada unsur riba, maisir, gharar, haram, dan zalim. Berbeda dengan akad Ijarah yang pada akhir akad tidak dapat terjadi peralihan hak atas objek sewa, Ijarah Muntahiya Bittamlik terdapat opsi perpindahan hak milik objek sewa. Peralihan hak milik objek sewa, hanya dapat dilaksanakan apabila akad Ijarah telah selesai dan sesuai dengan ketentuan Pasal 280 Kompilasi Hukum Ekonomi Syariah yang menyatakan:

1) Ijarah Muntahiya Bittamlik harus dinyatakan secara eksplisit dalam akad.

2) Akad pemindahan kepemilikan hanya dapat dilakukan setelah masa Ijarah Muntahiya Bittamlik berakhir.

Berdasarkan ketentuan Kompilasi Hukum Ekonomi Syariah opsi perpindahan hak milik objek sewa dapat dilakukan dengan akad jual beli, berdasarkan ketentuan Pasal 279 Kompilasi Hukum Ekonomi Syariah, Dalam akad Ijarah Muntahiya Bittamlik suatu benda antara $M u$ 'jir/pihak yang menyewakan dengan Musta'jir/pihak penyewa diakhiri dengan pembelian Ma'jur/obyek ijarah oleh Musta'jir/pihak penyewa. Dalam akad Ijarah Muntahiya Bittamlik menurut ketentuan Pasal 282Kompilasi Hukum Ekonomi Syariah, harga Ijarah dalam akad Ijarah Muntahiya Bittamlik sudah termasuk dalam pembayaran benda secara angsuran. Jadi berdasarkan ketentuan tersebut dapat diartikan bahwa, pembayaran sewa yang dilakukan oleh Mustajir telah termasuk dalam pembelian objek sewa secara angsuran.

Pasal 279 Kompilasi Hukum Ekonomi 
Syariah menentukan tata cara peralihan hak objek Ijarah Muntahiya Bittamlik yakni dengan akad jual beli pada saat akad Ijarah berakhir. Sehingga dalam akad Ijarah Muntahiya Bittamlik harus mencantumkan akad jual beli sebagai akad peralihan hak kepemilikan objek akad.

"BANK dengan ini menjual kepada NASABAH dan NASABAH membeli dari BANK atas barang Berupa: -

.... /sebagai dimaksud dalam Lampiran *) (selanjutnya disebut Barang)."

Berdasarkan pernyataan diatas akad Ijarah Muntahiya bittamlik telah memenuhi syarat dan rukun Ijarah yang dilakukan terlebih dahulu sesuai kemudian keabsahan akad untuk peralihan kepemilikannya sesuai dengan ketentuan Kompilasi Hukum Ekonomi Syariah dan aturan terkait lainnya.

\section{Peralihan Hak Objek Akad Ijarah Muntahiyah Bi Tamlik Yang Mencantumkan Janji Hibah Menurut Prinsip Syariah}

Berdasarkan penelitian terlebih dahulu oleh Evy Tamala, Konsep Mekanisme Pembiayaan Ijarah Muntahiya Bittamlik di PT. Bank Muamalat Syariah, Tbk menggunakan akad sewa-menyewa (Ijarah) dan pemindahan hak kepemilikan dengan akad jual beli sehingga telah sesuai dengan prinsip Islam. ${ }^{10}$ Pemindahan

\footnotetext{
${ }^{10}$ Evy Tamala, Konsep dan Aplikasi Peralihan Kepemilikan Pada Ijarah Muntahiyah Bittamlik (IMBT) Studi Komparatif (PT Bank Muamalat Syariah Indonesia dan Bank DKI Syariah Wahid Hasyim), Skripsi, Jakarta: Fakultas Syariah dan Hukum UIN Syarif Hidayatullah, 2010 , hlm. 84.

${ }^{11}$ Ibid, hlm. 86.
}

kepemilikan pada akad Ijarah Muntahiya Bittamlik pada Bank DKI syariah menggunakan dua jenis akad, yaitu akad jual beli (Murabahah) bila masa sewa diselesaikan sebelum masa sewa yang ditentukan berakhir serta akad hibah apabila masa sewa diselesaikan sesuai waktu yang telah ditentukan dan adapun pengikatan yang dilakukan agar kuat menurut ketentuan hukum adalah pemberian akta hibah oleh bank kepada nasabah. ${ }^{11}$

\section{Peralihan Hak Objek Akad Ijarah Muntahiya Bittamlik Dengan Janji (waad) Hibah}

Pada Dasarnya aktivitas usaha yang berdasarkan sistem perekonomian Islam mempunyai karakteristik sebagai berikut: ${ }^{12}$

1) Bersifat mandiri;

2) Sesuai dengan Syariat Islam;

3) Produk yang dihasilkan dapat memenuhi semua kebutuhan masyarakat;

4) Berprinsip mencari keuntungan;

5) Menerapkan fungsi efisiensi dan manfaat dengan menjaga kelestarian lingkungan.

Menurut Ibn Taimiyyah, manusia memiliki kebebasan yang cukup besar untuk mengadakan akad dan yang mereka butuhkan dalam rangka memenuhi kebutuhan hidupnya. Namun kebebasan itu bukan tidak terbatas, pembatasan tersebut terbagi dalam beberapa batasan yaitu: ${ }^{13}$

\footnotetext{
12 Ade Arthesa, dan Edia Handiman, Bank \& Lembaga Keuangan Bukan Bank, Jakarta: Indeks Kelompok Gramedia, 2006, hlm. 78.

13 Muslihun Muslim, Fiqh Ekonomi, Mataram: Lembaga Kajian Islam dan Masyarakat IAIN Mataram, 2005, hlm. 66.
} 
1) Kesepakatan dari para pihak yang membuatnya,

2) Kecakapan untuk mengadakan perjanjian,

3) Tidak dilarang oleh ketentuan syara,

4) Terhindar dari unsur judi dan riba,

5) Merealisasikan keadilan dan memberikan kewenangan kepada pemerintah untuk melaksanakan intervensi sepanjang bertujuan untuk menegakkan keadilan.

Jadi para pihak dapat bebas membuat akad sesuai dengan kesepakatan masingmasing dengan syarat tidak bertentangan dengan Prinsip Syariah. Hadits Nabi riwayat Ahmad dari Ibnu Mas'ud: Rasulullah melarang dua bentuk akad sekaligus dalam satu obyek. ${ }^{14}$ Menurut ketentuan-ketentun tersebut, dapat dimaknai bahwa untuk keabsahannya akad Ijarah Muntahiya Bittamlik harus dibuat terpisah antara akad Ijarah dan akad peralihan haknya. Jadi berdasarkan hadist tersebut Prinsip Syariah melarang penggabungan akad dalam satu transaksi.

Adapun ketentuan Kompilasi Hukum Ekonomi Syariah tentang keabsahan Akad Ijarah Muntahiyah Bittamlik menentukan bahwa opsi peralihan hak kepemilikan objek adalah dengan janji jual beli. Hal tersebut lebih ditegaskan pada ketentuan pasal 279 Kompilasi Hukum Ekonomi Syariah, Dalam akad Ijarah Muntahiya Bittamlik suatu benda antara Mu'jir/pihak yang menyewakan dengan Musta'jir/pihak penyewa diakhiri dengan pembelian Ma'jur/obyek Ijarah oleh Musta'jir/pihak penyewa.

Dalam akad Ijarah Muntahiya Bittamlik menurut ketentuan Pasal 282 Kompilasi Hukum Ekonomi Syariah, harga Ijarah dalam akad Ijarah Muntahiya Bittamlik sudah termasuk dalam pembayaran benda secara angsuran. Jadi berdasarkan ketentuan tersebut dapat diartikan bahwa, pembayaran sewa yang dilakukan oleh mustajir telah termasuk dalam pembelian objek sewa secara angsuran. Pasal 285 menentukan bahwa:

1) Apabila harga jual obyek Ijarah Muntahiya Bittamlik melebihi sisa utang, maka pihak yang menyewakan harus mengembalikan sisanya kepada penyewa.

2) Apabila harga jual obyek Ijarah Muntahiya Bittamlik lebih kecil dari sisa utang, maka sisa utang tetap wajib dibayar oleh penyewa.

3) Apabila peminjam sebagaimana dalam ayat (2) tidak dapat melunasi sisa utangnya, Pengadilan dapat membebaskannya atas izin pihak yang menyewakan.

Jadi dapat ditarik kesimpulan bahwa Kompilasi Hukum Ekonomi Syariah menentukan peralihan kepemilikan objek dengan janji (Waad) jual beli dan hanya mengatur sebatas akad Ijarah Muntahiya Bittamlik berdasarkan peralihan kepemilikan objek dengan janji (waad) jual beli, sehingga belum ada pengaturan tentang Akad Ijarah Muntahiya Bittamlik berdasarkan peralihan kepemilikan objek dengan janji (Waad) hibah.

Apabila peralihan kepemilikan objek

\footnotetext{
${ }^{14}$ Fatwa Dewan Syari'ah Nasional Nomor 27/DSNMUI/III/2002 tentang al-Ijarah Al-Muntahiyah Bi Al-Tamlik.
} 
dengan janji (Waad) hibah seperti bunyi akad yang tercantum:

"BANK dengan ini memberikan dan mengalihkan hak/kepemilikan (menghibahkan) kepada NASABAH yang menerangkan telah menerima dari BANK, atas:

/sebagai dimaksud dalam Lampiran *) (selanjutnya disebut Barang).”

Sedangkan pada ketentuan Pasal 6 akad Ijarah Muntahiya Bittamlik tercantum imbalan (Ujrah) yang diterima oleh Bank selaku pihak yang akan menghibahkan objek Akad Ijarah Muntahiya Bittamlik:

1. Imbalan atas Obyek Sewa (nilai sewa) sebagaimana dimaksud Pasal 2 Akad ini, harus dibayarkan sesuai jangka waktu sebagaimana dimaksud Pasal 5 Akad ini dan dibuat dalam bentuk Jadwal Pembayaran Imbalan yang merupakan satu kesatuan dan bagian tidak terpisah dengan Akad ini.

2. BANK dan NASABAH sepakat bahwa besarnya Imbalan sebagaimana dimaksud ayat 1 Pasal ini seluruhnya sebesar Rp.

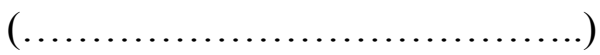
dan akan direview kembali setiap .... (.........) bulan. Imbalan tersebut belum termasuk pajak, dan biaya - biaya lain yang timbul akibat pembuatan Akad ini termasuk namun tidak terbatas pada biaya notaris, administrasi dan meterai.

Klausul adanya imbalan atas obyek sewa (nilai sewa) dalam akad tersebut sesuai dengan ketentuan Surat Edaran Bank Indonesia Nomor 14/10/Dpbs Tanggal 17 Maret 2008 Tentang Pelaksanaan Prinsip Syariah Dalam Kegiatan Penghimpunan Dana Dan Penyaluran Dana Serta Pelayanan Jasa Bank Syariah yang berbunyi:

"Membayar biaya sewa yang dapat dilakukan baik dengan angsuran maupun sekaligus".

Meskipun Prinsip Syariah mengenal adanya kebebasan berakad/ kebebasan berkontrak jadi para pihak dapat bebas membuat akad sesuai dengan kesepakatan masing-masing dengan syarat tidak bertentangan dengan Prinsip Syariah. Namun peralihan hak dengan akad hibah tersebut adalah tidak sah karena bertentangan dengan hibah berdasarkan prinsip syariah. Akad hibah berdasarkan prinsip syariah yang merupakan akad peralihan hak antara penghibah dengan penerima hibah secara cuma-cuma menurut ketentuan Pasal 693 Kompilasi Hukum Ekonomi Syariah Ijab dalam hibah dapat dinyatakan dengan kata-kata, tulisan, atau isyarat, yang mengandung arti beralihnya kepemilikan harta secara cuma-cuma.

Hal tersebut bertentangan karena ada imbalan yang harus diberikan Mustajirl nasabah kepada bank untuk objek akad Ijarah Muntahiya Bittamlik. Kedudukan bank sebagai penghibah dalam akad Ijarah Muntahiya Bittamlik tidak relevan karena bank adalah suatu badan usaha yang didirikan bertujuan mencari keuntungan.

\section{Perlindungan Hukum Terhadap Mustajir Dalam Akad Ijarah Muntahiya Bittamlik Berdasarkan Prinsip Syariah}

Hukum berfungsi sebagai perlindungan 
kepentingan manusia, agar kepentingan manusia terlindungi, hukum harus dilaksanakan secara profesional. Pelaksanaan hukum dapat berlangsung normal, damai, dan tertib. Hukum yang telah dilanggar harus ditegakkan melalui penegakkan hukum. Penegakkan hukum menghendaki kepastian hukum, kepastian hukum merupakan perlindungan terhadap tindakan sewenang-wenang. dengan adanya kepastian hukum masyarakat akan tertib, aman dan damai. Hukum dapat melindungi hak dan kewajiban setiap individu dalam kenyataan yang senyatanya, dengan perlindungan hukum yang kokoh akan terwujud tujuan hukum secara umum: ketertiban, keamanan, ketentraman, kesejahteraan, kedamaian, kebenaran, dan keadilan. ${ }^{15}$

Perlindungan hukum menurut Hajdon, terbagi menjadi dua yakni, Perlindungan hukum preventif, dan perlindungan hukum represif. ${ }^{16}$ Dalam akad Ijarah Muntahiya Bittamlik, bentuk perlindungan hukum baik perlindungan hukum preventif untuk melindungi hak-hak mustajir/nasabah dan mujir/bank terlihat dari tercantumnya ketentuan pada akad Ijarah Muntahiya Bittamlik bahwa apabila terjadi cedera janji oleh nasabah bank berhak untuk:

1. Menghentikan jangka waktu pemenuhan kewajiban BANK yang ditentukan dalam Akad ini dan meminta NASABAH untuk membayar sisa Imbalan serta mengembalikan atau menyerahkan kembali Obyek Sewa dalam kondisi baik; atau

2. Menjual harta benda yang

\footnotetext{
${ }^{15}$ Peter Mahmud Marzuki. Pengantar Ilmu Hukum,
} Jakarta: Kencana, 2008, hlm, 158. dijaminkan oleh NASABAH dan/atau Penjamin kepada BANK berdasarkan prinsip keadilan, baik dibawah tangan dengan harga yang disetujui NASABAH maupun dimuka umum (secara lelang) dengan harga dan syarat-syarat yang ditetapkan oleh BANK, dan untuk itu NASABAH/Penjamin memberi kuasa dengan ketentuan pendapatan bersih dari penjualan pertama-tama dipergunakan untuk pembayaran seluruh Imbalan yang masih terhutang oleh NASABAH kepada BANK dan jika ada sisa, maka sisa tersebut akan dikembalikan kepada NASABAH dan/atau Penjamin sebagai pemilik harta benda yang dijaminkan kepada BANK, dan sebaliknya, apabila hasil penjualan tersebut tidak cukup untuk melunasi seluruh kewajiban NASABAH kepada BANK, maka kekurangan tersebut tetap menjadi kewajiban NASABAH kepada BANK dan wajib dibayar NASABAH dengan seketika dan sekaligus pada saat ditagih oleh BANK.

Hal tersebut ditujukan demi keadilan dan untuk mencegah terjadinya sengketa. Dengan melindungi hak dari nasabah yang telah membayarkan harga Ijarah yang termasuk dalam pembayaran objek akad secara angsuran. Nasabah memiliki hak dari pembayaran sewa yang diberikan kepada bank sesuai dengan ketentuan Pasal 282 Kompilasi Hukum Ekonomi Syariah

\footnotetext{
${ }^{16}$ http://politkum.blogspot.co.id/2013/05/pengertian -perlindungan-hukum.html, diakses pada tanggal 18 April 2017.
} 
bahwa harga Ijarah dalam akad Ijarah Muntahiya Bittamlik sudah termasuk dalam pembayaran benda secara angsuran. Perlindungan bagi mujir/bank adalah bank berhak mendapatkan ganti kerugian apabila nasabah/ mustajir cedera janji.

Selain dalam bentuk tersebut terhadap hak pihak dalam akad dalam bentuk perlindungan preventif hak berupa Asuransi yang bertujuan melindungi hak mustajir dan hak bank bila terjadi sesuatu yang tidak dapat diprediksi kemudian hari dalam masa akad Ijarah berlangsung. Berdasarkan akad terlampir klausula asuransi terdapat dalam klausul ketentuan yang mewajibkan:

Selama kewajiban NASABAH sebagaimana dimaksud dalam Akad ini belum dipenuhi, maka barang agunan yang dapat diasuransikan wajib diasuransikan oleh dan atas beban NASABAH kepada Perusahaan Asuransi berdasarkan prinsip syariah yang ditunjuk dan atau disetujui oleh BANK terhadap risiko kerugian yang macam, nilai dan jangka waktunya ditentukan oleh BANK.

Pencantuman klausula asuransi dalam akad Ijarah Muntahiya Bittamlik bertujuan melindungi hak para pihak baik mustajirl nasabah sebagai penyewa dan mujir/ bank sebagai pemilik objek sewa. untuk perlindungan terhadap objek akad terhadap resiko kerugian dikemudian hari.

\section{PENUTUP}

Akad Ijarah Muntahiya Bittamlik telah memenuhi rukun dan syarat dalam Kompilasi Hukum Ekonomi Syariah. Pasal 278 Kompilasi Hukum Ekonomi Syariah Menyatakan Rukun dan syarat dalam Ijarah dapat diterapkan dalam pelaksanaan Ijarah Muntahiya Bittamlik. Rukun Ijarah
Pasal 251 Kompilasi Hukum Ekonomi Syariah sementara,

Peralihan hak objek akad Ijarah Muntahiya Bittamlik dengan mencantumkan akad hibah adalah tidak sah karena bertentangan prinsip syariah. Akad hibah merupakan akad peralihan hak antara penghibah dengan penerima hibah secara cuma-cuma menurut ketentuan Pasal 693 Kompilasi Hukum Ekonomi Syariah Hal tersebut bertentangan karena ada imbalan yang harus diberikan Mustajirl nasabah kepada bank untuk objek akad Ijarah Muntahiya Bittamlik.

Bentuk perlindungan Hukum Terhadap Mustajir Dalam Akad Ijarah Muntahiya Bittamlik adalah hanya berbentuk perlindungan hukum preventif yaitu perlindungan terhadap hak nasabah dalam pembayaran angsuran bila cedera janji dan penyertaan asuransi yang berbunyi objek akad wajib diasuransikan untuk perlindungan terhadap objek akad untuk perlindungan terhadap resiko kerugian dikemudian hari.

\section{DAFTAR PUSTAKA}

\section{Buku}

Ade Arthesa dan Edia Handiman, Bank \& Lembaga Keuangan Bukan Bank, Jakarta: Indeks Kelompok Gramedia, 2006

Chandra Natadipurba, Ekonomi Islam 101, Bandung: Mobidelta Indonesia, Bandung, 2015

Dhaniswara K. Harjono, Pemahaman Hukum Bisnis Bagi Pengusaha, Jakarta: Raja Grafindo Persada, 2006

Evy Tamala, Konsep dan Aplikasi Peralihan Kepemilikan Pada Ijarah Muntahiyah Bittamlik (IMBT) Studi 
Komparatif (PT Bank Muamalat Syariah Indonesia dan Bank DKI Syariah Wahid Hasyim), Skripsi, Fakultas Syariah dan Hukum UIN Syarif Hidayatullah, Jakarta 2010

Faturrahman Djamil, Penerapan Hukum Perjanjian dalam Transaksi di Lembaga Keuangan Syariah, Jakarta: Sinar Grafika, 2013

Lukman Hakim, Prinsip-prinsip Ekonomi Islam, Surakarta: Erlangga, 2012

Muslihun Muslim, Fiqh Ekonomi, Mataram: Lembaga Kajian Islam dan Masyarakat IAIN Mataram, 2005

Peter Mahmud Marzuki. Pengantar Ilmu Hukum, Jakarta: Kencana, 2008

Pusat dan pengembangan ekonomi Islam (P3EI) Universitas Islam Indonesia Yogyakarta berkerjasama dengan Bank Indonesia, Ekonomi Islam, Jakarta: Raja Grafindo Persada, 2008

Rachmandi Usman, Aspek Hukum Perbankan di Indonesia, Jakarta: Gramedia Pustaka Utama, Jakarta, 2001

\section{Jurnal}

Ahmad, "Penyelesaian Sengketa Ekonomi syariah di Pengadilan Agama", , JURNALIUS | Vol II | Nomor 6 | Desember 2014

Dewi Sartika Utami, "Akibat Hukum Pemberian Hibah yang Melebihi Batas legitime Portie (Analisis Kasus Putusan Pengadilan Negeri Nomor 109/pdt.g/2009/pn.mtr. Mengenai Hibah)", JURNAL IUS | Vol IV | Nomor 2 | Agustus 2016

Ida Ayu Wayan Meryawira Sendidevi, "Perlindungan Konsumen Dalam
Pemberian Jasa Layanan Perbankan Dan Sistem Pembayaran Melalui Rekening Ponsel Cimb Niaga", JURNALIUS | Vol III | Nomor 9 | Desember 2015

Luh Putu Vera Astri Pujyanti dan Amelia Kandisa, "Penyelesaian Sengketa Perbankan Melalui Mediasi Perbankan", JURNAL IUS | Vol III | Nomor 8 | Agustus 2015 